\title{
Enhanced detection of single-cell-secreted proteins using a fluorescent immunoassay on the protein-G-terminated glass substrate [Corrigendum]
}

Jeong Y, Lee KH, Park H, Choi J. Int J Nanomedicine. 2015;10:7197-7205.

On page 7204, Acknowledgment section was "This work was supported by the research fund of Hanyang University (HY-2014-2082)" however it should have been "This research was a part of the project titled "Development of early diagnosis technology of fishery viral diseases based on nanotechnology", funded by the Ministry of Oceans and Fisheries, Korea and the grant of the Korea Health Technology R\&D Project through the Korea Health Industry Development Institute (KHIDI), funded by the Ministry of Health \& Welfare, Republic of Korea (grant number: HI14C3266)".
The International Journal of Nanomedicine is an international, peerreviewed journal focusing on the application of nanotechnology in diagnostics, therapeutics, and drug delivery systems throughout the biomedical field. This journal is indexed on PubMed Central,

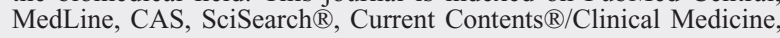

Journal Citation Reports/Science Edition, EMBase, Scopus and the Elsevier Bibliographic databases. The manuscript management system is completely online and includes a very quick and fair peer-review system, which is all easy to use. Visit http://www.dovepress.com/ testimonials.php to read real quotes from published authors. 